\title{
Mitigating the consequences of sexual violence in Zambia by decentralizing emergency medical responses to police victim support units: Report on the feasibility of police provision of post- exposure prophylaxis for HIV (PEP) in Zambia
}

\author{
Mary Zama \\ Population Council \\ Mardieh Dennis \\ Population Council \\ Jessica Price \\ Population Council \\ Stephanie M. Topp \\ Jonathan Kaunda Mwansa
}

See next page for additional authors

Follow this and additional works at: https://knowledgecommons.popcouncil.org/departments_sbsr-rh

Part of the Domestic and Intimate Partner Violence Commons, International Public Health Commons, Maternal and Child Health Commons, and the Women's Health Commons

How does access to this work benefit you? Let us know!

\section{Recommended Citation}

Zama, Mary, Mardieh Dennis, Jessica Price, Stephanie M. Topp, Jonathan Kaunda Mwansa, and Jill Keesbury. 2013. "Mitigating the consequences of sexual violence in Zambia by decentralizing emergency medical responses to police victim support units: Report on the feasibility of police provision of postexposure prophylaxis for HIV (PEP) in Zambia." Lusaka: Population Council. 


\section{Authors}

Mary Zama, Mardieh Dennis, Jessica Price, Stephanie M. Topp, Jonathan Kaunda Mwansa, and Jill Keesbury 
MITIGATING THE CONSEQUENCES OF SEXUAL VIOLENCE IN ZAMBIA BY DECENTRALIZING EMERGENCY MEDICAL RESPONSES TO ROLICE VICTIM SUPPORT UNITS

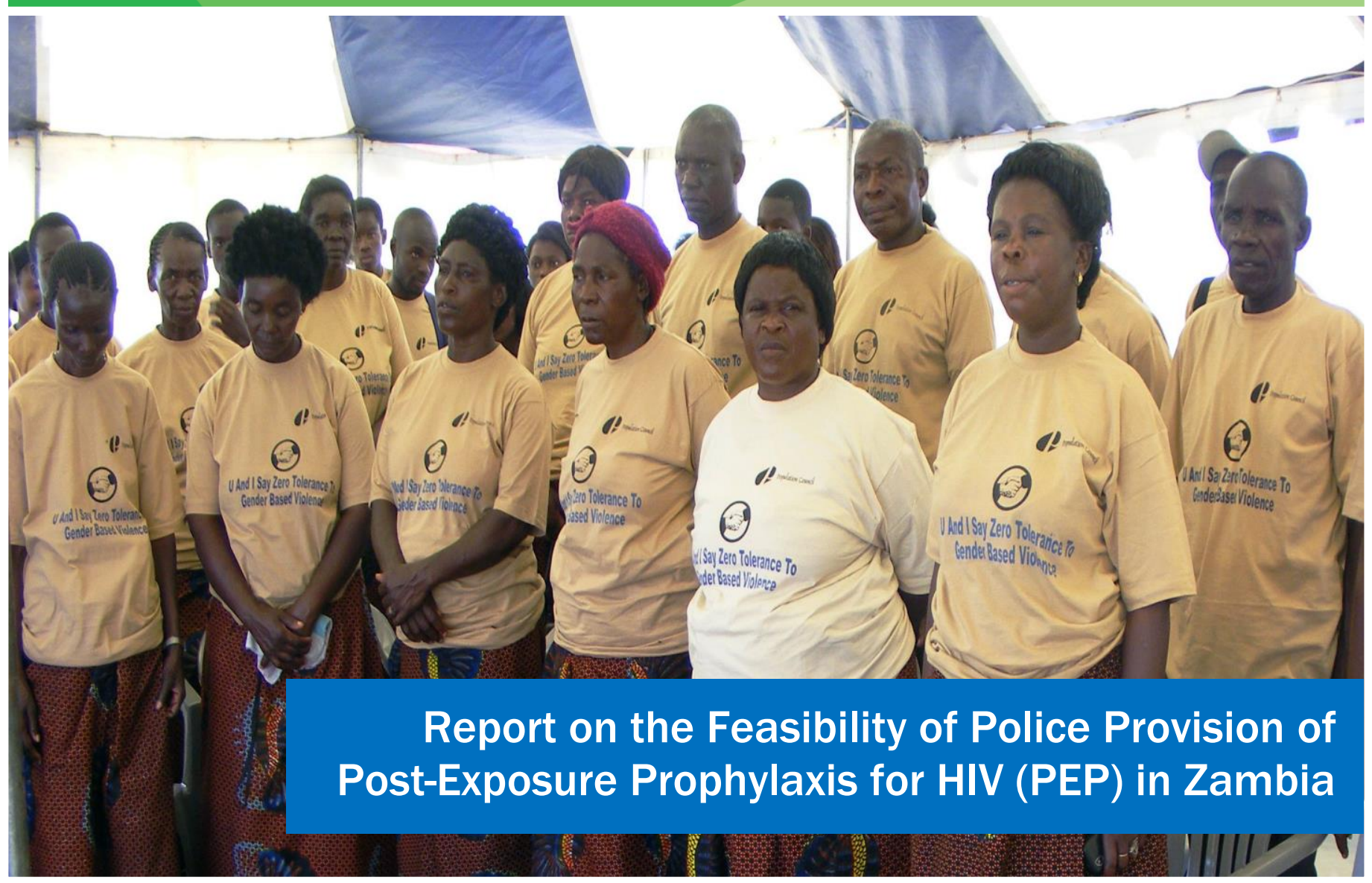

\section{dete} SWEDEN

Report on the Feasibility of Police Provision of Post-Exposure Prophylaxis for HIV (PEP) in Zambia 


\section{Mitigating the Consequences of Sexual Violence in Zambia by Decentralizing Emergency Medical Responses to Police Victim Support Units}

Report on the Feasibility of Police Provision of Post-Exposure Prophylaxis for HIV (PEP) in Zambia

Mary Zama ${ }^{1}$, Mardieh Dennis ${ }^{1}$, Jessica Price ${ }^{1}$, Stephanie Topp ${ }^{2}$, Dr. Jonathan Kaunda Mwansa ${ }^{3}$ and Jill Keesbury ${ }^{4}$

${ }^{1}$ Population Council

2Independent Consultant

${ }^{3}$ Arthur Davison Children's Hospital

${ }^{4} \mathrm{PATH}$ 


\section{POPULATION}

COUNCIL

Ideas. Evidence. Impact.

The Population Council confronts critical health and development issues-from stopping the spread of HIV to improving reproductive health and ensuring that young people lead full and productive lives. Through biomedical, social science, and public health research in 50 countries, we work with our partners to deliver solutions that lead to more effective policies, programs, and technologies that improve lives around the world. Established in 1952 and headquartered in New York, the Council is a nongovernmental, nonprofit organization governed by an international board of trustees.

Population Council

Plot No. 3670 4, Mwaleshi Road,

Olympia Park.

P/Bag Rw319x,

Lusaka, Zambia

Tel: +260 211295925

email: info.zambia@popcouncil.org

popcouncil.org

Suggested citation: Mary Zama, Mardieh Dennis, Jessica Price, Stephanie Topp, Jonathan Kaunda Mwansa and Jill Keesbury. 2013. Mitigating the Consequences of Sexual Violence in Zambia by Decentralizing Emergency Medical Responses to Police Victim Support Units: Report on the Feasibility of Police Provision of Post-Exposure Prophylaxis for HIV (PEP) in Zambia.

Lusaka: Population Council. 


\section{Acknowledgements}

The study also would have not been possible without the commitment and support of the Government of Zambia. The Zambia Police Service (ZP) supported the study at all levels, from the office of the Inspector General to the dedicated Victim Support Unit (VSU) Officers in the field. The National VSU Coordinator, Mr. Tresphord Kasale, Ms. Siamana Ndandula, Senior Assistant Commissioner of the ZP Protective Unit, and Mr. Fred Mulenga, Second Commanding Officer of the ZP Protective Unit, were actively involved in implementing the study and were instrumental in improving the police response to sexual violence cases. Director of Medical Services, Dr. George Msipu Phiri, and Chief Nursing Officer, Ms. Juliet Mwale Musabula, helped to strengthen the linkages between the police and medical sectors and ensured the availability of HIV postexposure prophylaxis and emergency contraception commodities at all of the study sites. Data collection and routine supervisory visits to the study sites were diligently supported by Inspector Nezza Nyirongo from the VSU national headquarters.

The Ministry of Health demonstrated equal commitment to the study through the national Reproductive Health and Disease Surveillance, Control, and Research units. We appreciate Dr. Jonathan Kaunda Mwansa, Pediatrician and Epidemiologist at Arthur Davison Hospital, for his active support of this work from its inception as a Principle Investigator. Dr. Swebby Macha, Gynecologist and Obstetrician at University Teaching Hospital (UTH), and Dr. Mutinta Muyuni Gynecologist and Obstetrician at Levy Mwanawasa Hospital, worked closely with the study coordinator to improve care for sexual violence in Lusaka. The senior managers at UTH were also committed to providing affordable, comprehensive medical services for survivors of sexual violence.

This study received financial support from the Swedish-Norwegian Regional HIV and AIDS Team for Africa. 


\section{Acronyms}

$\begin{array}{ll}\text { ART } & \text { Anti-retroviral therapy } \\ \text { ARV } & \text { Anti-retroviral (drug) } \\ \text { CMIC } & \text { Copperbelt Model of Integrated Care for Sexual Violence Survivors } \\ \text { EC } & \text { Emergency contraception } \\ \text { ECP } & \text { Emergency contraceptive pill } \\ \text { GBV } & \text { Gender-based violence } \\ \text { MCDMCH } & \text { Ministry of Community Development, Mother and Child Health } \\ \text { MOH } & \text { Ministry of Health } \\ \text { PEP } & \text { Post-exposure prophylaxis } \\ \text { VSU } & \text { Victim Support Unit } \\ \text { SV } & \text { Sexual violence } \\ \text { TA } & \text { Technical assistance } \\ \text { UTH } & \text { University Teaching Hospital } \\ \text { ZP } & \text { Zambia Police Service }\end{array}$




\section{Contents}

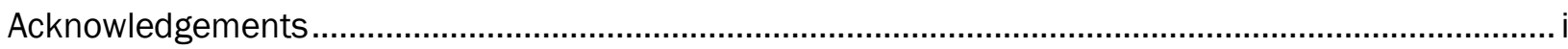

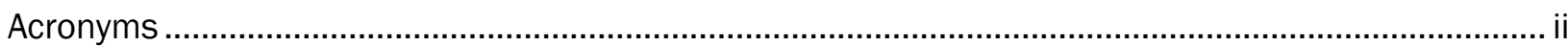

Background: Testing the Feasibility of Police-provision of Emergency Medical Care to Survivors of

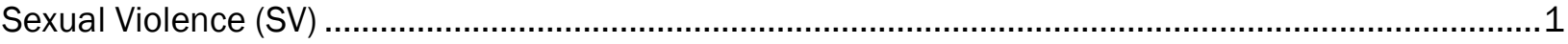

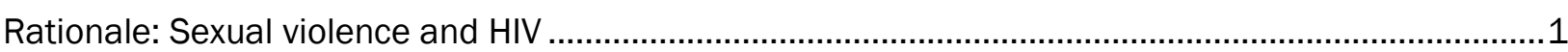

Technical Assistance Approach: Principles and Practice ….................................................................

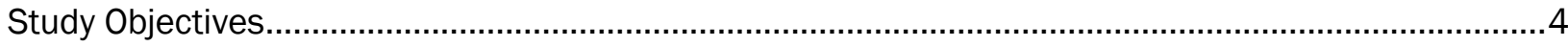

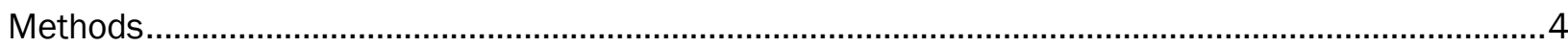

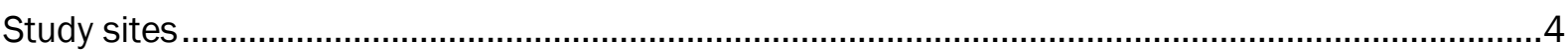

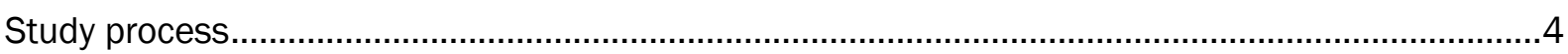

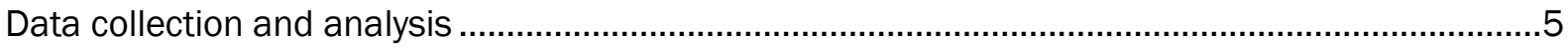

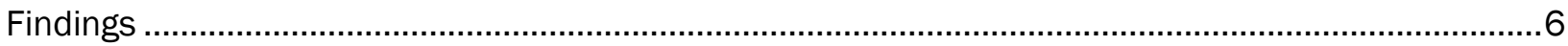

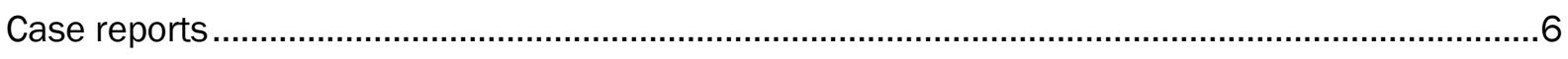

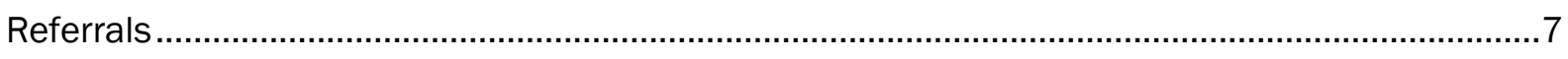

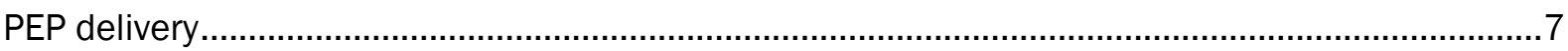

Open-ended Interviews and Focus Group Discussions ..............................................................

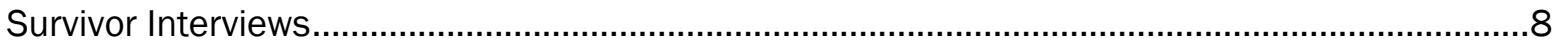

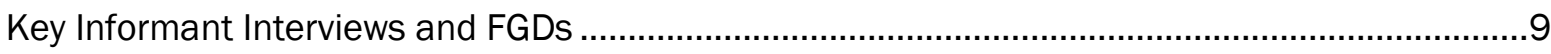

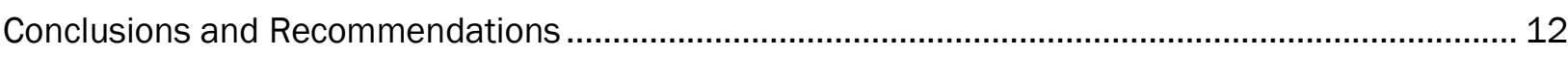




\section{Background: Testing the Feasibility of Police-provision of Emergency Medical Care to Survivors of Sexual Violence (SV)}

Since 2005, the Zambian Ministry of Home Affairs (housing the Zambia Police Service), the Ministry of Health, the Ministry of Community Development, Mother and Child Health (MCDMCH), and the Population Council have collaborated on operations research studies to increase provision of emergency medical care to survivors of sexual violence via the Zambia Police Services (ZP). This collaboration, with financial support from the Swedish-Norwegian Regional HIV and AIDS Team for Africa, has occurred in two main phases. The first phase, from 2005-2008, involved a study with ZP Victim Support Units (VSUs) in the Copperbelt to test the feasibility of police provision of emergency contraception (EC), a contraceptive method which prevents unwanted pregnancy within 120 hours of unprotected sex. The intervention - The Copperbelt Model of Integrated Care for SV Survivors (CMIC) - proved feasible ${ }^{1}$ and police delivery of EC was subsequently adopted as part of Zambia's national guidelines on the management of sexual violence. ${ }^{2}$

While this was a major advance in the government's response to SV, given Zambia's HIV prevalence of $14.3 \%$, the issue of preventing HIV acquisition in SV survivors remained a top priority. ${ }^{3}$ Encouraged by the results of the CMIC study and the 2007 World Health Organization guidelines on the provision of HIV post-exposure prophylaxis (PEP), which state that non-medical professionals can be trained to offer PEP, senior officials at the Ministry of Health (MoH) and ZP advocated for the provision of PEP to SV survivors at the earliest possible opportunity. ${ }^{4}$ The Council therefore collaborated with the $\mathrm{MoH}$ and ZP to develop a protocol for VSU officers to provide a PEP 3-day starter dose to SV survivors aged 10 years and older, with referral to a tertiary facility for comprehensive SV services. A study testing the feasibility of this protocol was conducted in two VSUs and their satellite sites in Lusaka from 2010 to 2013 . This report presents findings from the PEP feasibility study.

\section{Rationale: Sexual violence and HIV}

Worldwide, an estimated one in every three women will experience some form of gender-based violence (GBV) in their lifetimes. ${ }^{5}$ Defined broadly, GBV includes all forms of physical, psychological and sexual violence that are related to the victim's gender or gender role in a society or culture. ${ }^{6}$ This report focuses specifically on one form of GBV, sexual violence (SV),

\footnotetext{
1 Keesbury J et al. 2009. The Copperbelt Model of Integrated Care for Survivors of Rape and Defilement: Testing the Feasibility of Police Provision of Emergency Contraceptive Pills, Population Council, New York

2 Gender in Development Division. 2011. The National Guidelines for the Multidisciplinary Management of Survivors of Gender Based Violence in Zambia. Cabinet Office, Republic of Zambia. Lusaka

${ }^{3}$ Central Statistical Office (CSO), Ministry of Health (MOH), Tropical Diseases Research Centre (TDRC), University of Zambia, and Macro International Inc. 2009. Zambia Demographic and Health Survey 2007. Calverton, Maryland, USA: CSO and Macro International Inc.

4 World Health Organization, International Labor Organization. 2007. Post-Exposure Prophylaxis to Prevent HIV Infection: Joint WHO/ILO guidelines on post-exposure prophylaxis (PEP) to prevent HIV infection. HIV Programme. Geneva: WHO

5 United Nations Development Fund for Women. 2003. Not A Minute More: Ending Violence Against Women. http://www.unifem.org/campaigns/trust_fund_10th_anniversary/facts_figures.html

6 García-Moreno C, et al. 2005. WHO Multi-country Study on Women's Health and Domestic Violence Against Women World Health Organization, Geneva
} 
defined under Zambian law as rape of adult women or defilement of children under the age of 16.

GBV as a whole is a stigmatized and emotionally-charged issue in Zambia, as it is in many African countries. Only recently has it emerged a matter of public debate, benefitting from the attention given by the former First Lady, Mrs. Maureen Mwanawasa. While public recognition of GBV is growing in the country, reliable data on the nature and extent of such violence is limited. The 2007 Demographic and Health Survey (DHS) finding that 20\% of Zambian women between the ages of 15 and 49 have experienced some form of sexual violence gives some insight into the prevalence of sexual violence in the country.

The DHS data do not take into account sexual violence experienced by girls younger than 15 . However, results from research carried out by the Population Council suggest that the risk of SV in Zambia's young population is high. In a 2007 survey among school girls in urban Lusaka, 70\% of the girls reported being teased or sexually harassed verbally, $36 \%$ of respondents had heard of a schoolgirl in their community who was forced to have sex with a teacher, $23 \%$ had heard of a girl forced to have sex with a classmate, and $48 \%$ had heard of a girl forced to have sex with a relative from within her household. ${ }^{7}$ A 2011 survey in boys and girls from eight schools in urban and peri-urban Lusaka provide additional evidence. ${ }^{8}$ For girls and boys equally, 22 to $29 \%$ of respondents reported being sexually touched, with more boys (4.4\%) compared to girls $(1.4 \%)$ saying they had been sexually touched by teachers.

The risks associated with SV, especially among young women, are numerous. Immediate health consequences include unwanted pregnancy, physical trauma, emotional distress and acquisition of HIV and other sexually-transmitted infections. Especially pronounced in high HIV-prevalence countries, the linkage between gender-based violence and risk of HIV has been well documented in Africa. ${ }^{9}$ Infection following forced sex is likely to be higher than following consensual sex, especially among children. ${ }^{10}$ The increased violence associated with forced intercourse, and the lack of lubrication, can result in both microscopic and macroscopic mucosal tears. Forced anal penetration is thought to carry a commensurably higher risk of HIV transmission. ${ }^{11}$

Growing awareness of the negative consequences of GBV for individual and public health has led the Government of Zambia to adopt a comprehensive response that cuts across different service sectors. The National Guidelines for the Multidisciplinary Management of Survivors of Gender Based Violence in Zambia outlines the coordinated actions to be taken by the health, police and

\footnotetext{
7 Brady M, et al 2009. Understanding adolescent girls' protection strategies against HIV: An exploratory study in Zambia, Population Council, New York

8 Topp S, et al. 2011. Baseline Survey Results: School-related Sexual and Gender-based Violence -- Knowledge, Attitudes, and Practices Among Grades 8 to 11 Students in Lusaka, Population Council, New York

9 van der Straten A, et al. 1998. Sexual coercion, physical violence, and HIV infection among women in steady relationships in Kigali, Rwanda. AIDS and Behavior 2: 61-73; Maman S et al. 2002. HIV-positive women report more lifetime partner violence: findings from a voluntary counseling and testing clinic in Dar es Salaam, Tanzania. American Journal of Public Health 92: 1331-37; Dunkle K et al. 2004. Gender-based violence, relationship power, and risk of HIV infection in women attending antenatal clinics in South Africa. Lancet 363: 1415-21

10 Speight $C$ et al. 2006. Piloting post-exposure prophylaxis in Kenya raises specific concerns for the management of childhood rape. Transactions of the Royal Society of Tropical Medicine and Hygiene 100: 14-18

11 Drocton P, et al. 2008. Validation set correlates of anogenital injury after sexual assault. Academy of Emergency Medicine 15: 231-38; Girardet Ret al. 2009. HIV post-exposure prophylaxis in children and adolescents presenting for reported sexual assault. Child Abuse and Neglect 33: 173-78; Hilden M, et al. 2005. Genitoanal injury in adult female victims of sexual assault. Forensic Science International 154: 200-205
} 
social services sectors. The basic elements of such a response include clinical management of immediate injuries, police investigation, prosecution, and provision of immediate and long-term psychosocial support to survivors.

Central to both the police and medical sectors' response is their ability to coordinate with each other. This is especially pronounced in regard to the police and health services, which are often the first points of contact for the survivors. If delivered within 120 hours of unprotected sex, the emergency contraceptive pill (ECP) is effective in preventing unwanted pregnancy. ${ }^{12}$ To prevent HIV infection, the initial dose of anti-retroviral therapy (ART) needs to be given within 72 hours of exposure. ${ }^{13}$ Similarly, forensic evidence collection is time-sensitive and is also recommended within 72 hours of the assault. ${ }^{14}$ Responding within 72 hours following a sexual assault is, therefore, critical to ensure the health of the survivor and the ability to prosecute the case. The necessity of coordinating medico-legal responses in a limited timeframe makes linkages between these sectors a basic prerequisite for an effective institutional response to GBV.

\section{Technical Assistance Approach: Principles and Practice}

The PEP feasibility study has been as much about advocacy and mentoring as they have been about research and service implementation. Hence, alongside our preoccupation with methods for data collection and analysis, we have equally been concerned with building effective relationships with community, police and health sector leaders and other stakeholders. Rather than direct implementation of activities, our emphasis has been to provide technical assistance (TA) that leads to lasting, "country-owned" outcomes.

Similar to the TA principles described recently by Solter and Solter, 15 in working with ZP and $\mathrm{MOH}$ colleagues our approach has prioritized establishing trust. While advocating for particular approaches, building trust has required us to defer to the decisions and recommendations of national leaders and site level staff alike, as well as to accommodate the pace of change set by them. Communicating frequently, transparently, and consistently with all levels - from commanding officers to VSU officers in charge - of the police structure has been essential, enabling us to keep all of these critical actors informed and in the driver's seat. At the same time, for ad hoc consultation and as needed problem solving, Population Council technical staff has been made available at all times to police and health facility staff. Supportive supervision to participating VSUs and their posts was jointly conducted with Council technical staff and a VSU officer from ZP headquarters. These joint visits to the VSUs not only provided many mentoring opportunities, they also helped to ensure that the activities were ZP-valued and -owned, while the Council's role remained technical and supportive in nature.

12 Trussell J, et al. 2004. The role of emergency contraception. American Journal of Obstetrics and Gynecology 190: S40-38

13 World Health Organization, International Labor Organization. 2007. Post-Exposure Prophylaxis to Prevent HIV Infection: Joint WHO/ILO guidelines on post-exposure prophylaxis (PEP) to prevent HIV infection. HIV Programme. Geneva: WHO

14 Christian C, et al. 2000. Forensic evidence findings in prepubertal victims of sexual assault. Pediatrics 106: 100-04

15 Solter S, Solter C. 2013. Providing technical assistance to ministries of health: lessons learned over 30 years. Global Health: Science and Practice 1: 302-307 


\section{Study Objectives}

Recognizing the need to strengthen linkages between the police and the health sector and following on the lessons learned from the Copperbelt Model of police delivery of ECP, the PEP feasibility study was designed to:

i. determine if VSU officers could be trained to safely and effectively provide PEP to SV survivors

ii. explore ways to improve linkages and referrals between the ZP and the University Teaching Hospital (UTH) in Lusaka

An effective medico-legal response to SV requires that cases are reported in a timely manner. An additional objective of the study was therefore to:

iii. raise community awareness about SV and increase prompt reporting of cases to participating VSUs

\section{Methods}

\section{Study sites}

The PEP study took place between 2010 and 2013 in Chawama and Kanyama communities and police stations, including five police posts in Kanyama. Both are located in Lusaka Province and have an estimated combined catchment area population of around 296,000 inhabitants. Sites were selected in consultation with ZP and the $\mathrm{MOH}$. The high level of SV cases previously reported at these sites and the openness of VSU officers to participate in the study were the key selection criteria. To enable close medical monitoring, the study was confined to Lusaka sites.

\section{Study process}

Formative assessment: The research was carried out in three overlapping phases, beginning with a rapid assessment of the state of services available for SV survivors. To understand stakeholder concerns and to learn from their insights and perspectives, in this initial phase we conducted key informant interviews with $\mathrm{ZP}$ and $\mathrm{MOH}$ officials and personnel, with community leaders, and with anti-GBV advocates. The formative assessment also involved direct observation at police stations and at UTH in order to understand current practice and to identify training, referral, and infrastructure needs. Advocacy with stakeholders was critical during the formative assessment phase and throughout the whole project period, specifically to secure buy-in and support for piloting PEP provision at VSUs.

The intervention: The project involved distinct but interlinked interventions. In the first place, to enable provision of PEP by VSU officers, we conducted trainings that incorporated sensitization of police officers to a range of issues relating to sexual violence, orientation on procedures for PEP and ECP provision to SV survivors, and emphasis on multi-sectoral approaches. From May 2012 to October 2013, a total of $388 \mathrm{VSU}$ officers and representatives from ZP, MoH, and MCDMCH were trained on the multi-sector response to sexual violence and provision of the PEP starter dose with referral to UTH. Trainings took the form of intensive 10-day interactive workshops with a mix of participants, including VSU officers, health care providers from local facilities, reception 
officers from police stations and various other stakeholders. The trainings were co-facilitated by the Population Council, senior medical officers, the VSU national coordinator, the HR training manager from ZP, the director of medical services from ZP and counselors from the UTH OneStop Centre for child sexual abuse.

The project also developed job aids to guide officers in determining PEP eligibility and referral. Survivors considered eligible to receive PEP were:

\author{
i. $\quad \geq 10$ years \\ ii. Presented to the VSU within 72 hours of exposure \\ iii. Not currently on antiretroviral therapy (ART) \\ iv. Individuals who had experienced penetrative sex
}

PEP delivery to children younger than 10 years old requires calculating antiretroviral (ARV) dosages based on the child's weight. Due to this complexity, the project excluded children under the age of 10 from receiving VSU-based PEP. These children were referred directly to UTH's OneStop Centre. Other survivors eligible for PEP at the VSUs were given a start-dose of PEP and referred to UTH for follow-up with comprehensive SV services. Using tools produced in the Copperbelt Model feasibility study, VSU services also included ECP provision to eligible survivors.

To ensure VSUs had appropriate drugs and supplies to be able to deliver PEP and ECP, the project team worked to establish communication and supply chain systems between the $\mathrm{MOH}$ district pharmacy units (responsible for the ordering and distribution of all medical commodities within Lusaka), the ZP hospital and the participating VSUs. The Lusaka District Health Management Pharmacy Unit distributed the initial PEP supplies to the Lusaka Police Hospital. The Police Hospital's Nursing Services Unit, in turn, supplied these stocks to the participating VSUs. The VSUs were required to record the PEP doses used in a site-based register. At the end of the month, the Nursing Services manager collated this information and updated the Police Hospital's drugs register. An order was then placed by the Police Hospital to the Lusaka District pharmacy to 'pull' replacement supplies that were delivered to the Police Hospital and onwards to the VSUs.

\title{
Data collection and analysis
}

Survivor logbooks: On a monthly basis, a Population Council staff member and an officer from the national VSU Unit visited all project sites to review the survivor screening checklists for cases reported during the previous month and to transcribe data from the survivor log books to a study data collection sheet. Completed data collection sheets were stored at Population Council offices and data entered into an excel database. The data were then exported into Stata for descriptive statistical analysis.

Key informant interviews and focus group discussions: After 12 months of implementing the intervention, we conducted 16 one on one interviews and 6 focus group discussions with various stakeholders to elicit their perceptions of the activities, including successes, weaknesses, and the likelihood that they would be continued and scaled-up. We also asked informants about their recommendations for the future and to identify needs to ensure future success. All focus group discussions and most individual interviews were digitally recorded. For individuals who did not wish to be recorded, project staff took notes during the interview and wrote up fuller notes from 
memory immediately following the interviews. Partial transcription from digitally recorded interviews summarized the main ideas and included verbatim relevant quotes from the participant. Notes and transcripts were examined for critical themes and experiences relating to the context of sexual violence, availability of services, and follow up survivors.

Although we had initially planned to interview all PEP-eligible survivors, only eight agreed to participate in a follow-up interview. These eight women were interviewed using an open-ended interview guide designed to explore their experiences accessing SV services at ZP and UTH, including their frustrations experienced and gaps in the services. The interviews also explored the survivors' completion of PEP and asked them to describe what they found helpful and not helpful in this process as well as to offer recommendations for improving SV services.

\section{Findings}

\section{Case reports}

A total of 207 cases of sexual violence were reported at two police stations and four police posts during the project period (Table 1). One police post was excluded from data analysis because the VSU officer was absent and the logbook was inaccessible during each monthly monitoring visit. All 207 cases were female. Of note, 85\% involved girls under the age of 16 years, with the mean age of report being 13 years.

Table 1: Summary Case Statistics across Six Sites, November 2012 - October 2013

\begin{tabular}{|c|c|c|}
\hline $\begin{array}{c}\text { Data Extracted } \\
\text { Nov 2012 - Oct 2013 }\end{array}$ & Participating VSUs & University Teaching Hospital* \\
\hline Total Cases Reported & 207 & 156 \\
\hline Female & $100 \%$ & $99 \%$ \\
\hline Age (average) & 13.0 years & 17.3 years \\
$<10$ years & $47(23 \%)$ & $12(8 \%)$ \\
$10-16$ years & $129(62 \%)$ & $88(56 \%)$ \\
$17-24$ years & $15(7 \%)$ & $31(20 \%)$ \\
$>25$ years & $16(8 \%)$ & $25(16 \%)$ \\
\hline First Reported to Police & $97 \%$ & $62 \%$ \\
\hline
\end{tabular}

* Survivors at UTH enter through various clinics and are referred to gynecology or pediatric ward

Between the first and fourth quarters of the project, the number of SV cases reported to the participating VSUs increased by $56 \%$ (Figure 1). Of all cases, $65 \%(n=135)$ were reported within 72 hours of the SV incident. 


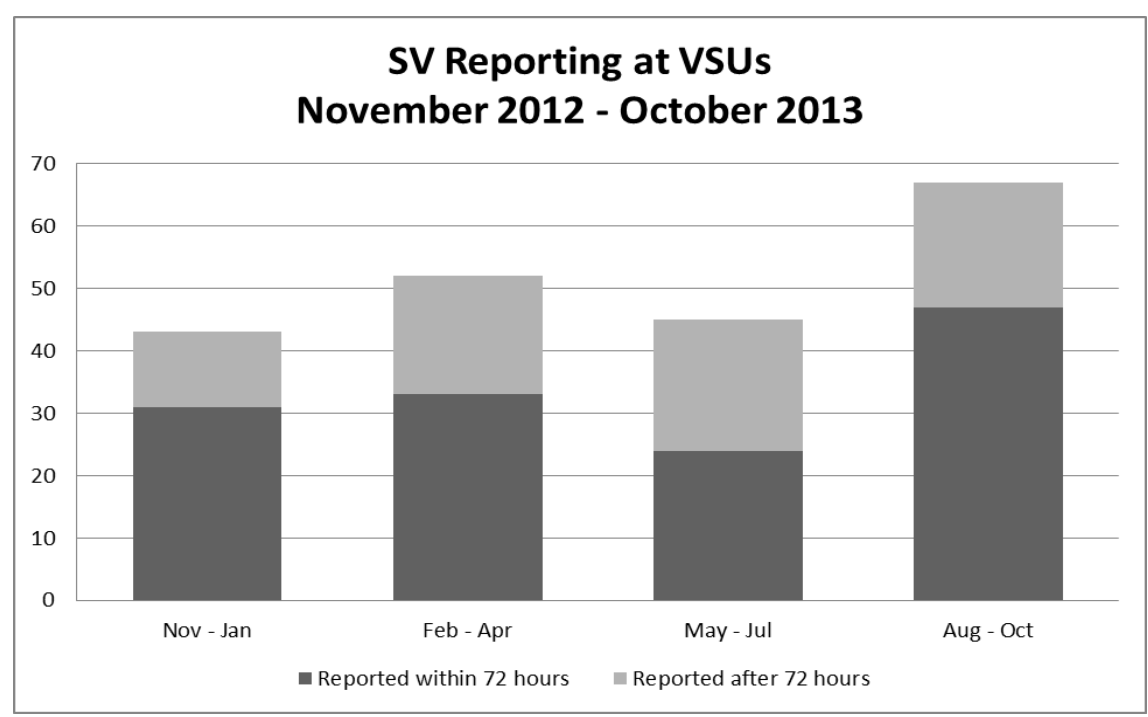

Only 53\% ( $n=110)$ of cases were reported during the VSU officers' official working hours. The remaining $46 \%(n=97)$ of cases were reported during the night or on weekends. Females over 16 years made up $20 \%$ of the cases reported during the night or on a weekend, versus $9 \%$ of those reported during working hours.

\section{Referrals}

The police provision of PEP protocol mandates that all SV cases be referred to UTH for further testing and treatment. According to the survivor log book records, $96 \%(n=199)$ of survivors who reported to the VSU were given the medical referral report form ZP32 and $84 \%(n=173)$ of survivors were referred to UTH. However, only $2 \%(n=4)$ were accompanied to the hospital by a police officer, as stipulated by the National Guidelines for the Multidisciplinary Management of Survivors of GBV. Since so few cases were accompanied to UTH, it is difficult to assess what proportion of cases actually made it to the hospital. For this reason we also extracted data about sexual assault cases reported at UTH that originated from the communities of interest to this project. These data were not linked to the police registers, but were collected to better understand the uptake and provision of PEP services in the health sector as compared with service delivery at the VSUs. UTH service records demonstrated that the hospital had fewer reports of sexual violence $(n=156)$ than were made through the police sites (Table 1). Almost all cases $(99 \%)$ at UTH were female. The average age of the survivors in the UTH records was substantially higher (17 years) compared to cases in the VSU records. Moreover, amongst these UTH cases recorded, 38\% had not reported to a police station prior to presenting at the hospital.

\section{PEP delivery}

For the purposes of this analysis, an eligible individual is one who reported to the police station within 72 hours of an SV incident and was 10 years or older. Of the 207 cases reported to the police, 135 (65\%) were reported within 72 hours of the assault (Figure 2). Of these, 31 were under 10 years old and therefore ineligible for police-initiated PEP; these girls were referred directly to UTH for follow-up care. 
Figure 2: Police Provision of PEP (November 1, 2012 - October 31, 2013)

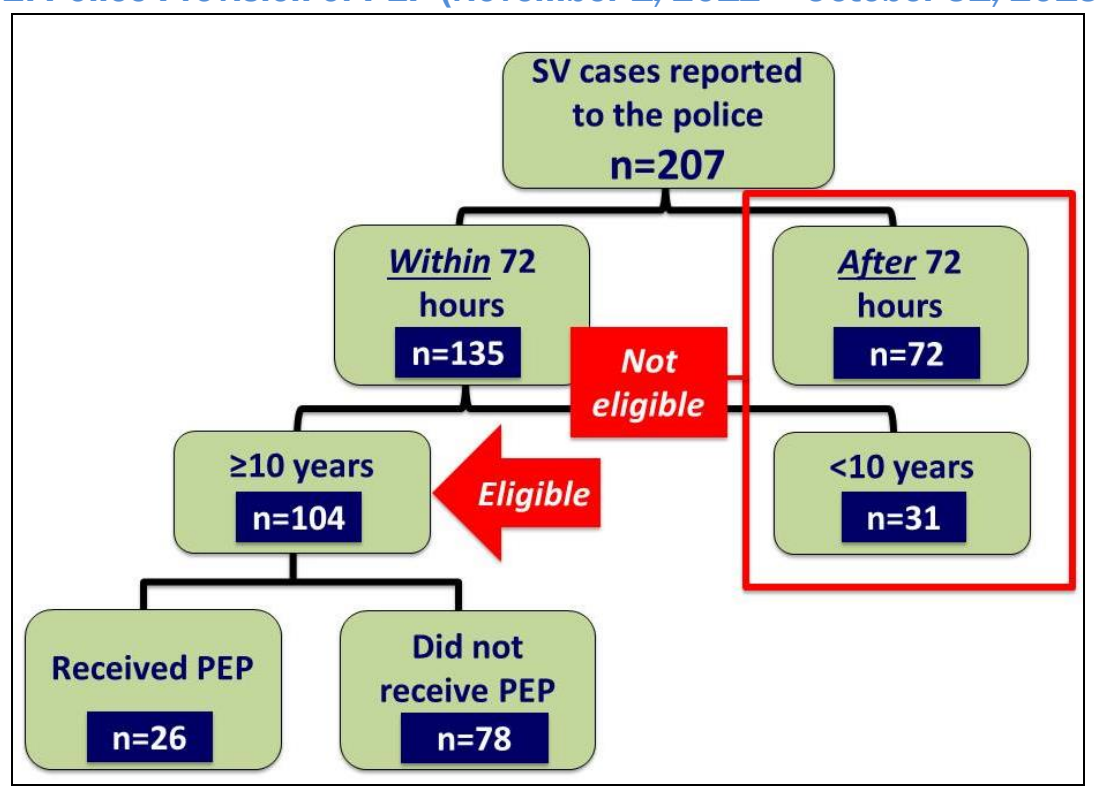

There are many possible explanations for why only $25 \%(n=26)$ of the remaining 104 eligible survivors actually received PEP. For instance, less than half $(n=49)$ of all eligible cases reported during the VSU officers' official working hours. While 33\% of eligible survivors who reported during official working hours received PEP, only $18 \%$ of those who reported on nights or weekends received PEP. Other possible explanations include:

i. the survivor presented when the VSU officer was on duty but away from his/her station

ii. the survivor was already on ART

iii. the survivor or her family refused PEP

iv. the incident did not involve penetrative sex

\section{Open-ended Interviews and Focus Group Discussions}

At the conclusion of the intervention period we conducted one-on-one interviews with survivors and key informant interviews and focus group discussions with representatives from ZP, MoH, $\mathrm{MCDMCH}$, and community members to elicit perceptions about the program's effectiveness.

\section{Survivor Interviews}

Survivors ranged in age from 14 to 28 years old (see Annex 1). With the exception of one case of consensual sex with a minor (case 2), the women and girls described brutal encounters involving physical violence and repeated rape. All of the girls ( $\leq 18$ years) were attacked in public places, while walking home from school, church, or the market, and two girls described being abducted by the minibus drivers who were transporting them home from school. The two adult women were attacked in their homes. A particularly dramatic incident (case 8) involved nighttime breaking-and-entry and an attempt by the perpetrator to murder the woman after raping her repeatedly over a four hour period. The violent nature of the incidents reminds us of the traumatized state of survivors as they seek help and justice and underscores the importance of experiencing a caring reception at police and health services. As sense of humiliation in situations lacking privacy was expressed by many of the women. 
Only four of nine cases reported at the police stations at a time when the VSU offices were open. In all four cases the women's reports of their experiences at the police station were positive, while the opposite was generally the case when the VSU officers were absent. With one exception, reception and inquiries officers were unhelpful, judgmental or both, suggesting a need to broaden sensitivity training and monitoring beyond VSUs.

\section{Key Informant Interviews and FGDs}

\section{Knowledge of SV survivor needs has increased, but "we need more time"}

Findings from the qualitative research illustrate an increase in knowledge and awareness of issues surrounding sexual violence and services available to survivors among both police officers and community members. A number of police officers interviewed commented that there had been a change in the way they understood and responded to reports of sexual violence. One officer explained that before being trained he "would just issue a medical report and refer the victim to the hospital", while afterwards he "had an in-depth understanding of the transmission of STIS and particularly HIV to victims and...could exercise empathy towards the victim as opposed to the ridicule that they were subject to before when they blamed the victims for sexual violence."

Focus group discussions with the GBV community clubs also indicated greater community-level awareness and understanding of GBV issues and preventive services. As one member of a GBV community club noted, "before the project started, we did not know what to do about sexual violence; but now we are able to advise people on what steps to take and where to go.'

Supporting these claims, both police and community members perceived an increase in the number of sexual violence cases being reported and the uptake of PEP \& ECP at police stations. According to another GBV club member, "before, people were ignorant...but after we carried out sensitizations at churches, schools, markets the community at large started reporting [sexual violence] cases [to the police]."

While these are very positive developments, it is important to acknowledge that critical gaps in knowledge and understanding still exist. One police officer reported that some survivors feared that accepting PEP would indicate to others that they were HIV-positive and wanted to avoid the stigma associated with taking drugs. Officers also reported that some survivors did not seek further care at the hospital, believing that the starter dose of PEP that they received from the police station was sufficient for preventing HIV transmission. Despite various sensitization efforts, established beliefs and norms about what constitutes sexual violence and how it should be handled also remained prevalent among many community members.

\section{Feasibility of police delivery of PEP has been demonstrated, but "we now need to decentralize access more"}

Community members noted that the provision of PEP at police stations substantially improved survivors' access to the drugs, as compared with a hospital-only model. According to one participant, "it is a good thing that $[P E P]$ is now being offered at police stations since they are close to the community and hence the drugs are easily accessible." However, issues such as human resource gaps, fragmentation and weak coordination between sectors, and weak infrastructure continue to limit access to comprehensive HIV prevention services for SV survivors. 
Police and community participants both noted that the lack of trained VSU officers available during night and weekend shifts was an ongoing barrier to service delivery and discouraged survivors from reporting to the police. One police officer notes that "some victims come to report cases at night when VSU officers have knocked off" and as a result, "survivors have no one to attend to them." Furthermore, a community member explains that when survivors are turned away from the police station, "they start to feel the process is too long and end up going back home without having acquired the services they set out to get."

Several police officers recommended that offering comprehensive SV services at community health centers; recruiting additional VSU officers; and allowing non-VSU officers to provide PEP would increase access to SV services. Community members also suggested that further decentralization (e.g. provision of PEP through trained members of GBV community clubs) would increase access to SV services, particularly when VSU officers are not on duty. One GBV club member recommended that "members of the community should also be able to administer PEP $\&$ ECP to survivors. It is feasible, just like members of the public have been trained to administer TB drugs."

Access to the full course of PEP is also impeded by the availability of only one referral hospital to provide comprehensive SV services and the distance between the communities and the hospital. Several police officers reported that despite survivors receiving a starter dose of PEP at the police station, lack of transport money often prevented them from reporting to the hospital for follow-up treatment and forensic evidence collection. One officer notes that having UTH as the only referral facility makes the services inaccessible because "some sexual violence survivors cannot afford to take their cases to [the hospital] as they have no money for transport."

Lack of a discretionary vehicle available to VSU officers to transport survivors also undermined the continuity of comprehensive SV care. As explained by a police officer, "the police often do not have transport because the station vehicle is busy with other duties." These challenges are major contributors to the weak linkages between police and health services and help explain the higher number of cases reported to the police compared to UTH.

\section{Prevailing Social Norms}

Both the quantitative data and the interviews with police officers and community members illustrate that certain social norms prevent certain cases from being taken to the police. Police officers and community members report that through outreach activities, there is a growing belief within the communities that SV against children is a crime that must be reported. Of the 207 SV cases reported to the participating sites, $85 \%$ involved girls younger than 16 years. As one GBV club member noted: "In the past, sexual violence issues were resolved at household level or by pastors at church or elders. Today, parents, guardians, neighbors, the community at large, they all come to [the GBV community club] if they notice anything suspicious with their children...and we can [verify] and report."

As noted in the quantitative findings, however, the proportion of adult women survivors reporting to the participating sites was comparatively small (only $15 \%$ of all cases were above 16 years). Participants in the endpoint interviews explained that access to SV services adult women continues to be influenced by prevailing social norms around GBV. As described by one club member: "Most women who are raped do not report for reasons such as shame, stigma, and 
fear of being beaten up by their partners or losing their marriages." These social norms were also evident in reports of the continued victimization of adult women by some police officers, including asking survivors to produce witnesses or requesting payment, which likely acted as a deterrent to service uptake.

Even stronger taboos relating to the discussion and reporting of sexual violence perpetrated against boys and men were evident in the absence of any reports by, or on behalf of, boy-child or adult male survivors. Previous Population Council research ${ }^{2}$ has shown that sexual abuse of boychildren in a sample of Lusaka schools was equally, if not more prevalent, than that against girls, suggesting that strong social norms continue to inhibit both recognition of and intervention in such cases. One key informant, a senior police officer, alluded to this taboo as well, suggesting that it certainly was a barrier to help-seeking for male victims of sexual violence.

\section{Relationship between the Community and the Police}

While progress has been made to improve the relationship between the police and the community in relation to the reporting and handling of sexual violence cases, some key informant experiences demonstrate that there is still a significant amount of distrust between the two groups.

Strong demand for and uptake of PEP \& ECP services requires community members to have adequate information about the service and trust that it will be provided in an ethical and respectful manner. Multiple reports from the qualitative interviews indicate that the establishment and training of the GBV clubs resulted in greater community awareness of the VSU unit and the services it provided. The increase in the number of cases reported to the police is also suggestive of some improved levels of trust: "The response of the community has been positive ... After we carried out sensitizations at churches, schools, markets, the community at large started reporting cases." One GBV club member reported that "the community and police are now working hand in hand."

Similarly, police officers reported that their training combined with community sensitization activities had improved the relationships between the community and the police: "The PEP/ECP project has tremendously improved relations between the community and the police. It has helped build confidence between the general public and the police. The knowledge [we] have acquired as police officers has enabled [us] to interact better with the community and hence has acted as a bridge between the community and the police."

Despite these positive reports, some tensions remain between police and community members. A number of GBV club members made comments relating to the poor attitudes and lack of cooperation of police officers, indicating a lingering undercurrent of distrust in relation to the police force. One complaint reported was that "the police do not give feedback on cases reported by members of the GBV club. They do not want to share information [making] it hard for us to follow up." Further, they explain that the police still doubt the survivors' reports of SV, noting that "the police tease victims saying they asked for it especially if they were raped whilst out at night." 


\section{Conclusions and Recommendations}

This feasibility study confirms that Zambian police officers can effectively and correctly provide SV survivors with a three-day starter pack of PEP and refer them to health services for follow-up. However, the study also highlights issues needed to improve program effectiveness.

- Increase access to PEP services at VSUs: Ideally, PEP should be available at VSUs on all days and at all hours of the day. It was apparent from the small number of survivors we were able to interview that closed VSUs and the absence of trained VSU officers negatively affect the survivors' experiences and may result in missed opportunities to intervene with PEP and ECP in a timely fashion.

- Expand sensitivity training to other officers: If VSU offices cannot remain open and staffed 24 hours a day and 7 days a week then at a minimum we recommend expanding SV sensitivity training to other attending and in-charge officers and equipping them to effectively refer survivors to health services. Further, through pre-service and refresher trainings, all Zambian police officers should be educated on the rights of SV survivors.

- Strengthen management and monitoring systems: It was not possible to determine from routine police data why PEP-eligible survivors did not receive PEP when they presented at VSU. In order to better identify the challenges and strengthen police PEP delivery, police should be required to report why each case was not given PEP. One likely explanation is that the VSU officer was not on duty when the survivor presented. Over $50 \%$ of the cases captured through the police registers were reported during the evenings or on weekends, outside of the VSU officers' official working hours. However, this does not explain all cases. We suspect that the lack of services may also be due to competing demands on the VSU officers' time and disruptions in the PEP supply.

- Decentralize PEP delivery to primary health centers: Because of crowding and demand on health providers' time to attend to many urgent cases, the UTH gynecology and maternity wards are ideal sites to attend to cases of sexual violence. Additionally, the distance between police stations and UTH made referrals, transportation and police-escorts difficult. Decentralizing the provision of PEP to primary health centers, who are already delivering HAART for HIV treatment and prevention of mother-to-child transmission, could help resolve these issues and ensure that survivors receive timely care.

- Strengthen community-based responses to cases of SV and to facilitate PEP access: Community groups and Sexual and Gender-based Violence Committees are increasingly engaged in promoting awareness of SV and advocating for survivor rights. These emergent community-based structures are primed to take on more direct service delivery roles - in counseling, referrals, case advocacy and case management, and perhaps even PEP delivery - to improve community responses to SV. In future work we would advise testing ways to most effectively tap into and empower existing community structures to improve responses to cases of SV. In particular, a local-level coordination or case management role to assist survivors move through emergency and follow up medical process and to access support for legal follow and psycho-social care seems especially pertinent. 


\begin{tabular}{|c|c|c|c|c|}
\hline Case & Age & The Incident and Resort to the VSU & Access to and Experience at the VSU & Referral to and Experience at UTH \\
\hline $\begin{array}{c}1 \\
\text { “Giselle” }\end{array}$ & 18 & $\begin{array}{l}\text { Giselle was abducted by minibus driver on } \\
\text { her way home from school and raped } \\
\text { repeatedly throughout the night until she } \\
\text { escaped at } 4: 30 \text { in the morning. The rapist's } \\
\text { sister and neighbor were witness to the } \\
\text { abduction, both apparently familiar with this } \\
\text { behavior, and did nothing to assist the girl. } \\
\text { Follow up: Giselle completed the HAART cours } \\
\text { settlement to avoid going to court. Her parents }\end{array}$ & $\begin{array}{l}\text { When Giselle arrived home her parents took } \\
\text { her to the police. The VSU officer was present } \\
\text { and sympathetic. He administered PEP and } \\
\text { ECP and asked Giselle's parents to take her } \\
\text { to UTH for follow up. When asked to describe } \\
\text { the most helpful aspects in her help-seeking } \\
\text { Giselle replied: The police didn't shout at me. } \\
\text { and was found HIV-negative and not pregnant. } \\
\text { refused. }\end{array}$ & $\begin{array}{l}\text { Giselle reported to the maternity ward reception } \\
\text { and referred to the gynecology ward. With so } \\
\text { many people present at both UTH locations, she } \\
\text { was uncomfortable relating her story: I felt like } \\
\text { everyone thought I was a whore. Otherwise, } \\
\text { providers at UTH were very kind and offered } \\
\text { thorough counseling. } \\
\text { The rapist's sister came to Giselle's home seeking }\end{array}$ \\
\hline $\begin{array}{c}2 \\
\text { "Sarah" }\end{array}$ & 14 & $\begin{array}{l}\text { Sarah's is a case of statutory rape. When her } \\
\text { parents learned that she was sneaking out } \\
\text { of the house to meet up with a } 20 \text { year old } \\
\text { man, they took her to the police. Sarah } \\
\text { wanted to marry the man because, she } \\
\text { explained, he gives me everything I want. } \\
\text { Follow up: Unclear from the interview }\end{array}$ & $\begin{array}{l}\text { The VSU officer was present and interviewed } \\
\text { Sarah in private and provided her with ECP } \\
\text { and PEP, which Sarah was happy to take. } \\
\text { Like Giselle, Sarah was most happy with the } \\
\text { fact that the police officer did not shout at } \\
\text { her. }\end{array}$ & $\begin{array}{l}\text { Sarah's parents took her to UTH's One Stop } \\
\text { Center, which treats cases of sexual violence } \\
\text { against children. Although she appreciated the } \\
\text { counseling, Sarah was annoyed by being } \\
\text { repeatedly told that she was too young to marry } \\
\text { or to be having sex. }\end{array}$ \\
\hline $\begin{array}{c}3 \\
\text { "Beatrice" }\end{array}$ & 17 & $\begin{array}{l}\text { Beatrice was abducted by a minibus driver } \\
\text { on her way home from school and raped } \\
\text { repeatedly in a nearby bush. She could hear } \\
\text { passers-by and screamed for help, but no } \\
\text { one came to her aid. The rapist beat her for } \\
\text { screaming. When he finished raping her, } \\
\text { around 8:00 at night, he drove her to her } \\
\text { parents' house and dropped her off at the } \\
\text { gate. Her father opened the door and looked } \\
\text { shocked to see his daughter in torn clothes. } \\
\text { Follow up: Beatrice completed the HAART cour } \\
\text { Beatrice's home seeking settlement to avoid c }\end{array}$ & $\begin{array}{l}\text { Beatrice's mother took her to the police. The } \\
\text { VSU officer was present and sympathetic. } \\
\text { She administered PEP and ECP and then } \\
\text { gave Beatrice Form ZP32 to take to UTH } \\
\text { gynecology ward for follow up. The VSU } \\
\text { officer called UTH to alert them of Beatrice's } \\
\text { referral. Most helpful to Beatrice was that } \\
\text { the VSU officer was very supportive and... } \\
\text { She said it wasn't my fault. } \\
\text { se and went for all medical follow up. The rapist } \\
\text { ourt but her parents refused. }\end{array}$ & $\begin{array}{l}\text { Beatrice reported and registered at the maternity } \\
\text { reception and was directed promptly to health } \\
\text { personnel who were expecting her. She was } \\
\text { attended to immediately and counseled. While } \\
\text { the health personnel were kind, she was } \\
\text { uncomfortable relating her story. } \\
\text { was apprehended by police. His relatives came to }\end{array}$ \\
\hline
\end{tabular}




\begin{tabular}{|c|c|c|c|c|}
\hline Case & Age & The Incident and Resort to the VSU & Access to and Experience at the VSU & Referral to and Experience at UTH \\
\hline $\begin{array}{c}4 \\
\text { “Holly" }\end{array}$ & 18 & $\begin{array}{l}\text { Holly was raped on the night of } 1 \text { st January, } \\
\text { 2013. No other details are clear from the } \\
\text { interview. } \\
\text { Follow up: Holly completed her HAART course }\end{array}$ & $\begin{array}{l}\text { When Holly arrived at the police she was told } \\
\text { that the VSU offices were closed. The officer } \\
\text { she found gave her forms to complete and } \\
\text { she was asked to go to the gynecology ward } \\
\text { at UTH. She was not provided with transport } \\
\text { so her parents had to look for transport } \\
\text { money. The attending officer made me feel } \\
\text { guilty in a way by putting the blame on how I } \\
\text { was dressed. }\end{array}$ & $\begin{array}{l}\text { Holly reported and registered at the maternity } \\
\text { reception at UTH and later to the gynecology } \\
\text { ward. The doctor took long in attending to her as } \\
\text { he was attending to other patients. }\end{array}$ \\
\hline $\begin{array}{c}5 \\
\text { "Roxy" }\end{array}$ & 14 & $\begin{array}{l}\text { Roxy went to the market with her friends to } \\
\text { buy vegetables for her mother. On their way } \\
\text { home, the girls were cornered by a group of } \\
\text { men. Roxy tried to run away but was caught } \\
\text { by one of the men and raped behind a bush. } \\
\text { The other men from the group walked by as } \\
\text { she was being attacked and ignored what } \\
\text { was happening. Her rapist left and she } \\
\text { walked home alone crying. } \\
\text { Follow up: Roxy completed PEP and attended } \\
\text { refused. }\end{array}$ & $\begin{array}{l}\text { When Roxy arrived home, her parents took } \\
\text { her to the local police station. The } \\
\text { perpetrator was apprehended and jailed. Her } \\
\text { mother informed her uncle about the } \\
\text { incident and he encouraged her to take Roxy } \\
\text { to his community's police station, where they } \\
\text { offer survivors HIV prevention services. } \\
\text { Roxy's uncle took her to the VSU and she } \\
\text { was counseled, given a medical report form, } \\
\text { and referred to UTH. She was not given PEP } \\
\text { at the VSU. } \\
\text { ler follow up visits. The rapist's family requested }\end{array}$ & $\begin{array}{l}\text { A nurse at the children's OPD attended to Roxy, } \\
\text { administering HIV and pregnancy tests. Both } \\
\text { tests were negative and she was given PEP and } \\
\text { ECP. A doctor conducted a gynecological exam } \\
\text { and gave her a schedule for follow up visits. }\end{array}$ \\
\hline $\begin{array}{c}6 \\
\text { "Frida" }\end{array}$ & 17 & $\begin{array}{l}\text { Frida was on her way from church with } \\
\text { friends when she was attacked by men and } \\
\text { raped twice in the nearby bush. She and her } \\
\text { friends screamed for help but no one } \\
\text { stopped or came to her aid. }\end{array}$ & $\begin{array}{l}\text { Frida's uncle took her to the police but the } \\
\text { VSU office was closed. The attending officers } \\
\text { were unkind. One of them even asked me } \\
\text { "what were you doing out at night? Was it not } \\
\text { your boyfriend?" }\end{array}$ & $\begin{array}{l}\text { Frida's uncle took her to UTH, where she reported } \\
\text { to the maternity wing reception. With so many } \\
\text { pregnant women needing attention, Frida was } \\
\text { referred to the gynecology ward where she } \\
\text { received PEP, ECP, and counseling. The doctor } \\
\text { was called in and only came after two hours. He } \\
\text { took some specimen and prescribed other } \\
\text { medicines. }\end{array}$ \\
\hline & & \multicolumn{3}{|c|}{ Follow up: Frida was given a follow up visit schedule. } \\
\hline
\end{tabular}




\begin{tabular}{|c|c|c|c|c|}
\hline Case & Age & The Incident and Resort to the VSU & Access to and Experience at the VSU & Referral to and Experience at UTH \\
\hline $\begin{array}{c}7 \\
\text { “Jane" }\end{array}$ & 14 & $\begin{array}{l}\text { Jane had just gotten off of the bus on her } \\
\text { way home from school, when a man grabbed } \\
\text { her from behind and forced her into an } \\
\text { empty construction building and raped her. } \\
\text { She screamed for help, attracting the } \\
\text { attention of men passing by who came to } \\
\text { her aid. They chased the rapist away and } \\
\text { escorted Jane home. } \\
\text { Follow up: She was asked to attend a follow ur }\end{array}$ & $\begin{array}{l}\text { Some neighbors helped Jane and her mother } \\
\text { get to the VSU in a taxi. The VSU office, } \\
\text { however, by the time she arrived. The } \\
\text { attending officer referred Jane to the UTH } \\
\text { One Stop Center (OSC) that deals with cases } \\
\text { of sexual violence in children, but it too was } \\
\text { closed. } \\
\text { visit. }\end{array}$ & $\begin{array}{l}\text { As the OSC was closed a doctor in the children's } \\
\text { outpatient department attended to Jane, giving } \\
\text { her PEP, ECP and other medicines to prevent } \\
\text { other infections. She was asked to report back } \\
\text { the next morning, but was unable to do this due } \\
\text { to a lack of transportation. Five days later an } \\
\text { OSC officer collected samples despite warning } \\
\text { her that they might not be as effective. }\end{array}$ \\
\hline $\begin{array}{c}8 \\
\text { "Yvonne" }\end{array}$ & 26 & $\begin{array}{l}\text { Yvonne woke from her sleep and found a } \\
\text { stranger hovering over her. He tied her up } \\
\text { and raped her repeatedly over a } 4 \text { hour } \\
\text { period, from about midnight to } 4 \text { am. The } \\
\text { rapist then robbed her, wrapped her in } \\
\text { bedding and clothing, sprinkled paraffin on } \\
\text { her and set her on fire. The beddings were } \\
\text { damp, allowing Yvonne to free herself and } \\
\text { seek help from her neighbors. }\end{array}$ & $\begin{array}{l}\text { At } 6: 00 \text { in the morning she was escorted to } \\
\text { the police station by her neighbors. The VSU } \\
\text { officer was not yet on duty, but the inquiries } \\
\text { officer was sympathetic, equipped Yvonne } \\
\text { with a ZP Form 32, and referred her to UTH. } \\
\text { Her neighbors pooled money for a taxi to the } \\
\text { hospital and one of them accompanied her } \\
\text { there. }\end{array}$ & $\begin{array}{l}\text { Yvonne presented at the Maternity Ward } \\
\text { reception, where she had to recount her trauma } \\
\text { in the presence of other patients. She was } \\
\text { registered and referred from Maternity to the } \\
\text { Gynecology Ward. When she arrived there were } \\
\text { many patients and the nurses transferring shifts. } \\
\text { After some time she was seen by a nurse and she } \\
\text { again relayed her story of the rape and attempted } \\
\text { murder. She waited several hours to see the } \\
\text { doctor and finally decided to leave at } 11 \text { am, } \\
\text { having received no medications or provided any } \\
\text { specimens up to that point. She returned to the } \\
\text { VSU and was given PEP and ECP. The VSU officer } \\
\text { escorted Yvonne back to UTH for follow up and he } \\
\text { personally took Yvonne's specimen to the lab. }\end{array}$ \\
\hline & & \multicolumn{3}{|c|}{ Follow up: Yvonne completed her PEP and attended all follow up visits. } \\
\hline
\end{tabular}




\begin{tabular}{|c|c|c|c|c|}
\hline Case & Age & The Incident and Resort to the VSU & Access to and Experience at the VSU & Referral to and Experience at UTH \\
\hline $\begin{array}{c}9 \\
\text { "Tina" }\end{array}$ & 25 & $\begin{array}{l}\text { Tina was sweeping outside her home when a } \\
\text { man grabbed her from behind; forced her } \\
\text { into her house; and raped her. Upon hearing } \\
\text { her screams, neighbors came to her aid and } \\
\text { apprehended the rapist. Although they } \\
\text { helped her, Yvonne described, I was so } \\
\text { ashamed and didn't know what to do. } \\
\text { Everyone knew what happened to me. I'm a } \\
\text { single woman and now I don't know what my } \\
\text { neighbors will think of me. } \\
\text { Follow up: Tina completed her PEP and attend }\end{array}$ & $\begin{array}{l}\text { The neighbors took both Tina and her rapist } \\
\text { to the police. She described, with so many } \\
\text { people just looking at me, was humiliating. A } \\
\text { crowd of onlookers wanted to see the } \\
\text { suspect and the woman who'd been raped. I } \\
\text { was so embarrassing. I just wanted a place } \\
\text { to hide myself from this world. I felt like } \\
\text { dying. The VSU officer, however, was } \\
\text { comforting. He dispersed the crowd and } \\
\text { attended to me. } \\
\text { ed all follow up visits. Her case has not yet been }\end{array}$ & $\begin{array}{l}\text { Tina was escorted to UTH by a VSU officer. The } \\
\text { nurse-in-charge administered HIV and pregnancy } \\
\text { tests, both of which were negative. Tina was seen } \\
\text { by a male doctor, and she felt ashamed sharing } \\
\text { her story with him. As a result, he called in a } \\
\text { female nurse, who remained in the room while } \\
\text { the doctor conducted a full gynecological } \\
\text { examination. She was given a full course of PEP } \\
\text { and given a follow up visit schedule. } \\
\text { taken to court. }\end{array}$ \\
\hline
\end{tabular}

